\title{
Antioxidant capacity and sustainability of Saccharomyces cerevisiae cells exposed to ozone
}

\author{
I. P. Goriacha ${ }^{1}$, V. D. Zinchenko', T. S. Dyubko ${ }^{1,2}$, E. A. Romodanova ${ }^{3}$, A. L. Tatarets ${ }^{2}$ \\ ${ }^{1}$ Institute for Problems of Cryobiology and Cryomedicine, NAS of Ukraine \\ 23, Pereyaslavskaya Str., Kharkiv, Ukraine, 61015 \\ ${ }^{2}$ State Scientific Institution «Institute for Single Crystals», NAS of Ukraine \\ 60, Lenin Ave., Kharkiv, Ukraine 61178 \\ ${ }^{3}$ National University of Pharmacy \\ 53, Pushkinska Str., Kharkiv, Ukraine, 61002 \\ irynagor@gmail.com; vd_zin@mail.ru
}

\begin{abstract}
Aim. The investigation of response of S. cerevisiae cells to the effect of ozone in different doses and determination of total antioxidant capacity (TAC) of these cells. Methods. TAC was estimated with the chemiluminescent method when introducing ozone into $S$. cerevisiae cells. The damage of cells was determined by the methods of fluorescent microscopy and flow cytometry using fluorescent dye Square-460. Results. It was shown that under the ozone dosed administration into the $S$. cerevisiae cells suspension the chemiluminescence flash occurred in response to each new ozone doze. The flash amplitude slightly changes under low doses and decreases after achieving some total ozone dose, being characteristic for these cells. At the same time the damaged cells appear, the number of which augments with increasing the administered ozone dose. Conclusions. We assessed the TAC of S. cerevisiae cells, as the ozone dose, which may be neutralized by the systems of their antioxidant protection: $240 \pm 20 \mathrm{nmol} / 10^{6}$ cells. The $S$. cerevisiae cells are resistant to the effect of excessive ozone until its doses exceed the TAC value for these cells.
\end{abstract}

Keywords: oxidative stress, reactive oxygen species, ozone, S. cerevisiae, chemiluminescence.

Introduction. The impact of ozone on the functional activity of microorganisms is multidirectional, depending on the ozone dose. For instance, low doses of ozone stimulate respiration and reproductive capability of microorganisms, whereas high doses thereof inhibit these processes and result in the death of cells [1,2]. The response of microorganisms to ozone follows the general picture of the biological system response to the stress. The effect of the vital functions stimulation using low doses of the stimulant (for weak stress) is observed for different living systems, from bacteria to plants, animals and humans [3].

The adjustment of cells and organisms to different types of stresses is of interest due to the response of the living systems to the change in the environment, the stu-

(C) Institute of Molecular Biology and Genetics, NAS of Ukraine, 2014 dy of the effect of medical preparations on the human organism, and the elaboration of the treatment methods.

Like other reactive oxygen species (ROS) - hydrogen peroxide, superoxide, etc., - ozone causes the oxidative stress for the living systems, upsetting the proand antioxidant balance therein [4]. This induces the response of the biological system, which, as well as the response to other kinds of stress, is non-linear and dependent on the dose of ozone [5]. The character of the dose dependence of the living system response to ozone is similar to the character of the response to the activity of other inductors of the oxidative stress.

The study of the adaptive response of $S$. cerevisiae yeasts to the oxidative stress, caused by hydrogen peroxide, allowed determining three remarkable ranges of hydrogen peroxide concentrations. After the pre-treatment of cells with hydrogen peroxide in the concentra- 
tion of less than $0.5 \mathrm{mmol}$, the rate of their division and growth increased by 15-30\% compared to the cells which have not been pre-treated. The increase in the concentration of hydrogen peroxide to $1 \mathrm{mmol}$ led to the decrease in the number of surviving cells up to $10 \%$ compared to the control, and the concentration of $3 \mathrm{mmol}$ led to the death of cells [6].

Three dose ranges were also observed while studying the adaptive response of $\mathrm{S}$. cerevisiae cells to the impact of ozone: low doses (13-42) pmol/106 cells; medium doses (42-240) pmol/10 $10^{6}$ cells; and high doses - over $300 \mathrm{pmol} / 10^{6}$ cells. The $S$. cerevisiae and E. coli cells, treated with low doses of ozone (about 15 $\mathrm{pmol} / 106$ cells), restore the indices of division and growth after their external freezing-thawing better than the non-treated cells [7]. The impact of low doses of ozone is explained by the hormesis - the «favorable» effect of the stress factor on the organism [3]. Medium doses of ozone cause reversible inhibition of the division and growth of cells, whereas high doses lead to their death.

It is known that the character of the cell response to the stimulant (the activation of vital processes or their inhibition and damage of cells) reflects the degree of the damage to the living system homeostasis under the effect of the stimulant as a stress factor. However, if the effect of the stress factor is in the acceptable range in terms of its intensity, the cell or the organism is capable of adjusting and surviving [3]. When ozone is used as an external stimulant, the degree of damage to the cell homeostasis is determined by the dose of the introduced ozone or the intensity of the oxidative stress, caused by ozone [5].

The capability of cells to resist the oxidant effect, causing the oxidative stress, is measured by the total antioxidant status (TAOA) or the total antioxidant capacity (TAOC) of cells.

The terms TAOA and TAOC are often interchanged, although they have different meanings. The term «TAOC» is intended for the data on the number of free radicals or ROI in the non-radical form, available for the antioxidant system to interact, which preconditions the duration of the antioxidant effect $[8,10]$.

The term TAOA describes the initial dynamics of the antioxidant activity, characterized by the constant value for the rate of the corresponding reaction [9]. In our opinion, it would be more reasonable to measure the TAOA of $S$. cerevisiae cells in order to determine their resistance to the ozone effect. Similar approach is widely used to monitor the antioxidant status of different biological objects $[10,11]$.

The aim of the current work is to study the resistance of $S$. cerevisiae cells to the effect of different doses of ozone and to determine the TAOA of the abovementioned cells.

Materials and methods. The investigation was performed using S. cerevisiae cells (Y-126, obtained via the Research Institute of the Chemical Industry of the Russian Federation from the Central Museum of Industrial Microorganisms, the All-Russia Research Institute of Genetics). The yeasts were grown in the slant wort agar for $48 \mathrm{~h}$ at $30{ }^{\circ} \mathrm{C}$ and washed from the nutrient medium with the physiological saline solution. The physiological saline solution was prepared using analytically pure sodium chloride («Reanal», Hungary). The study was conducted using the suspensions with the cell concentration of $(5 \pm 0.1) \cdot 10^{7}$ cells $/ \mathrm{ml}$. All the estimations were performed at $20 \pm 1{ }^{\circ} \mathrm{C}$.

Ozone was obtained using the electrosynthesis, flowing the gaseous oxygen through the barrier discharge ozone generator [12] and dissolving via barbotage in the physiological saline solution at the temperature of thawing ice. The concentration of the dissolved ozone in the ozonous physiological saline solution (OPSS) was determined using the Specord UV VIS spectrophotometer («Carl Zeiss», Germany), estimating the optic density of the solution at the wavelength of $255 \mathrm{~nm}$ (Hartley band) [13]. The ozone concentration in OPSS was brought up to $1-5 \mathrm{mg} / 1$ depending on the dose of the ozone, required for the introduction into the suspension of cells.

The chemiluminescence (CL) was observed on the bioluminometer with the spectral sensitivity range of 300-380 $\mathrm{nm}$ [14]. The cuvette with the suspension of $S$. cerevisiae cells in the concentration of $5 \cdot 10^{7}$ cells $/ \mathrm{ml}$ was placed into the bioluminometer. The reaction was initiated by the introduction of 0.1 OPSS with the required ozone concentration into $0.5 \mathrm{ml}$ of the cell suspension. The burst of luminescence was registered using the computer, connected to the bioluminometer via the interface.

In the work we used the fluorescent probe, a squaraine dye Square-460 («SETA» BioMedicals, USA). The 

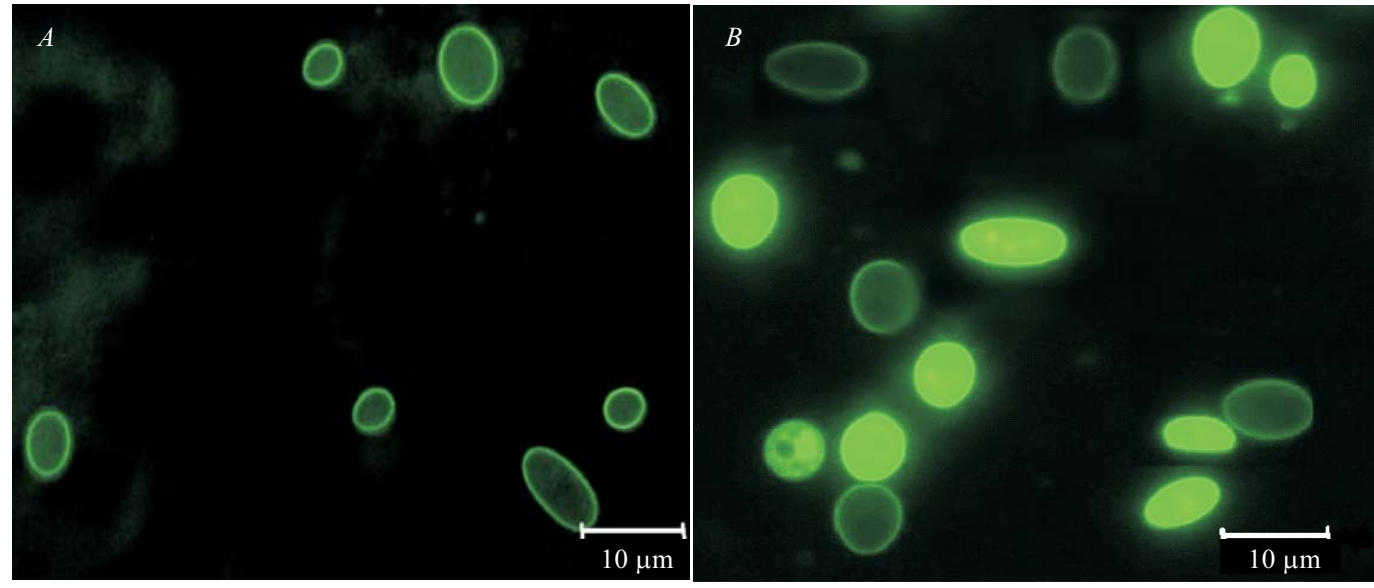

Fig. 1. S. cerevisiae cells, dyed with Square-460: $A$ - cells, not treated with ozone; $B$ cells after the ozone impact in the dose of $280 \mathrm{pmol} / 10^{6}$

solutions of the fluorescent dye were prepared using the ethyl alcohol. The cells were dyed by $15-\mathrm{min}$ incubation in the medium with Square-460 dye in the concentration of $40 \mu \mathrm{mol} / 1$, with the subsequent washing of the free dye during centrifugation for $3 \mathrm{~min}$ at $800 \mathrm{~g}$. The dye was introduced into the cells suspension after their treatment with ozone. The distribution of cells, dyed with Square-460, in terms of the fluorescence intensity was studied using the flow cytofluorometer BD FACS Calibur (USA). The fluorescence of cells was excited by the argon laser (the wavelength of $488 \mathrm{~nm}$ ) and registered in the FL2 channel (the wavelength of $578 \mathrm{~nm}$ ) where the fluorescence of the damaged and non-damaged cells has more differences in terms of its intensity compared to the channels FL1 and FL3 (the wavelength of 530 and $650 \mathrm{~nm}$, respectively).

When the results are presented in the SSC-FL2 coordinate system, the damaged cells are registered in the right part of the dot diagram, as their being dyed with Square-460 causes higher fluorescence intensity compared to that of non-damaged cells. The ratio of the damaged and non-damaged cells was estimated using WinMDI 2.9 software.

The fluorescent microphotographs were obtained using the Axio Observer Z1 confocal laser scanning microscope («Carl Zeiss»). The Filter set 10 («Carl Zeiss») with the excitation waves of $450-490 \mathrm{~nm}$ and the emission of 516-565 nm was used in the work.

The results are presented using the data of at least five independent experiments. The statistical processing of the obtained results was conducted using the Origin 8.5 software. The data were estimated using Student's $t$-test. The results are presented in the form of average arithmetic values, their dispersion is described using the average mean-square error $(\mathrm{p}<0.05)$.

Results and discussion. The ability of the fluorescent dye Square-460 to stain the living and necrotic cells differently was used to observe the cells damage. Fig. 1 presents the fluorescent microphotographs of Square-460-dyed S. cerevisiae cells.

It is evident that the probe dyes only the envelopes of the non-damaged cells and has limited penetration through the envelope, which is also confirmed by less bright cytoplasm fluorescence (Fig. 1, $A$ ). Fig. 1, $B$, is the image of the cells after the introduction of the ozone dose of $280 \mathrm{pmol} / 10^{6}$ cells. The field of vision contains some cells, the cytoplasm of which has bright fluorescence, which we believe to be the indication of the probe penetration into the cells due to the death of the cell.

Fig. 2 presents dot diagrams of the fluorescence of $S$. cerevisiae cells, obtained using the flow cytofluorometer, which illustrate the impact of different doses of ozone on the cells integrity.

At the ozone doses of $36 \mathrm{pmol} / 106$ cells (Fig. 2, B) and $64 \mathrm{pmol} / 10^{6}$ cells (Fig. 2, C) the image of dot diagrams does not differ from the control (Fig. 2, A). The damaged cells constitute less than $10 \pm 2 \%$ of the total population, which slightly changes under the impact of the mentioned doses of ozone.

At the ozone dose of $240 \mathrm{pmol} / 10^{6}$ cells (Fig. $2, D$ ) the number of the damaged cells is $25 \pm 5 \%$ of the total population. The increase of the ozone dose to 320 pmol $/ 10^{6}$ cells (Fig. $2, E$ ) leads to the increase in the number of the damaged cells up to $70 \pm 5 \%$. At the dose of $2.2 \cdot 10^{3} \mathrm{pmol} / 10^{6}$ cells (Fig. $2, F$ ) all the cells are in the area, corresponding to that of the damaged cells. 


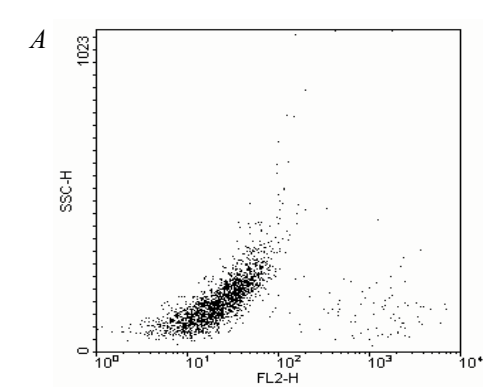

D
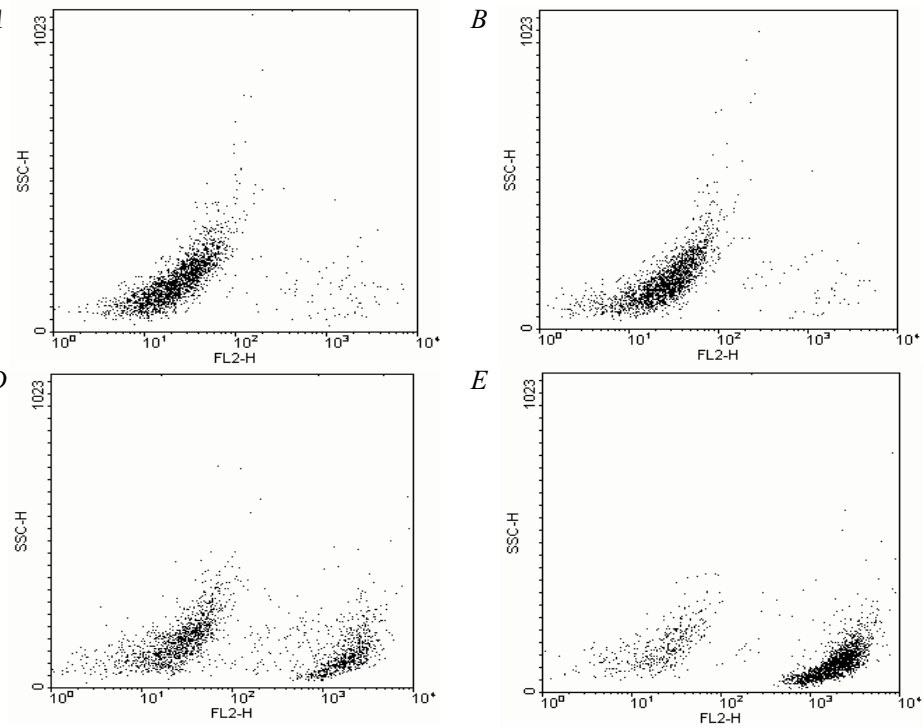

E

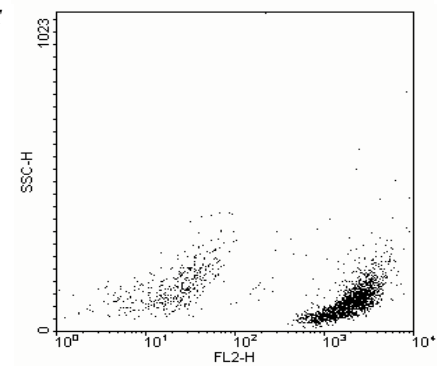

C

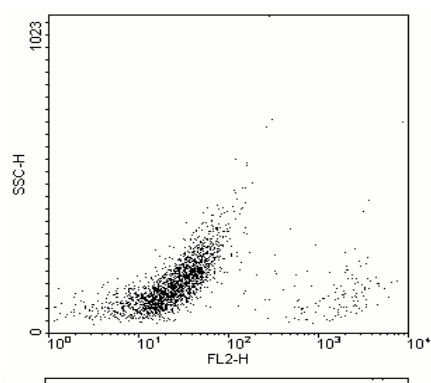

F

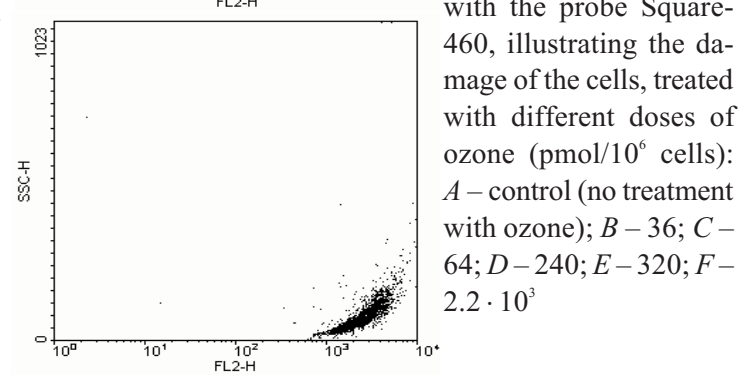

Fig. 2. The dot diagrams of the fluorescence of $S$. cerevisiae cells, dyed with the probe Square460 , illustrating the damage of the cells, treated with different doses of ozone (pmol $/ 10^{6}$ cells): $A$ - control (no treatment $240 ; E-320 ; F$

the excess of the externally introduced ROS. For this

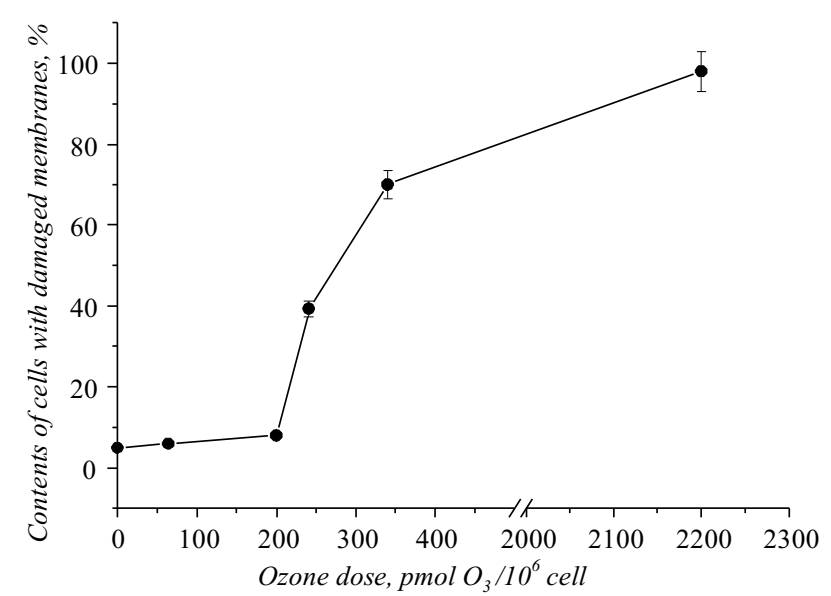

Fig. 3. The dependence of the number of the damaged $S$. cerevisiae cells on the ozone dose; $\mathrm{p}<0.05$ compared to the control

Fig. 3 demonstrates the dependence of the number of the damaged $S$. cerevisiae cells on the ozone dose, calculated on the basis of the processed dot diagrams of fluorescence.

The number of the damaged cells is slightly varying at the ozone doses of under $240 \mathrm{pmol} / 10^{6}$ cells and is rapidly increasing after the introduction of higher ozone doses into the cell. Therefore, when exceeding some threshold dose, ozone causes the cells damage, which is registered by the increase in the fluorescence intensity of Square-460-dyed cells.

To estimate the impact of ozone on $S$. cerevisiae cells, we used the method of determining TAOC, based on the analysis of the capability of cells to neutralize purpose a dosed amount of ROS in the form of ozone is introduced into the cell, and the index of TAOC is estimated as the maximal amount of ozone, capable of neutralizing the antioxidant systems of the cell.

The method is based on our discovery of the phenomenon of CL of the living cells at the introduction of ozone therein. The CL response is present at the introduction of a weaker oxidant - hydrogen peroxide - into the cells. The $\mathrm{CL}$ is not observed at the introduction of ozone into the cells, inactivated by heating to $100{ }^{\circ} \mathrm{C}$. We have not found any reports in the available literature about the observation of the living cells in response to the introduction of low doses of ozone. In our opinion, the emission of light in response to the introduction of ozone into the cells is related to the processes of ROS disposal by the systems of the antioxidant protection of the cells. The clarification of the mechanism of this phenomenon requires further studies. Fig. 4 demonstrates the oscillographic images of the series of the bursts of $\mathrm{CL}$ at the introduction of portions of the ozonous physiological saline solution into the suspension of S. cerevisiae cells.

The amplitude of the chemiluminescence response of the cells to ozone is slightly changing at the ozone dose in each portion of $30 \mathrm{pmol} / 10^{6}$ cells, whereas the total dose of the introduced ozone does not reach the values much above 200 pmol $/ 10^{6}$ cells (Fig. 4, A). At a higher ozone dose in each portion $\left(240 \mathrm{pmol} / 10^{6}\right.$ cells $)$ the amplitude of the bursts decreases up to complete ab- 

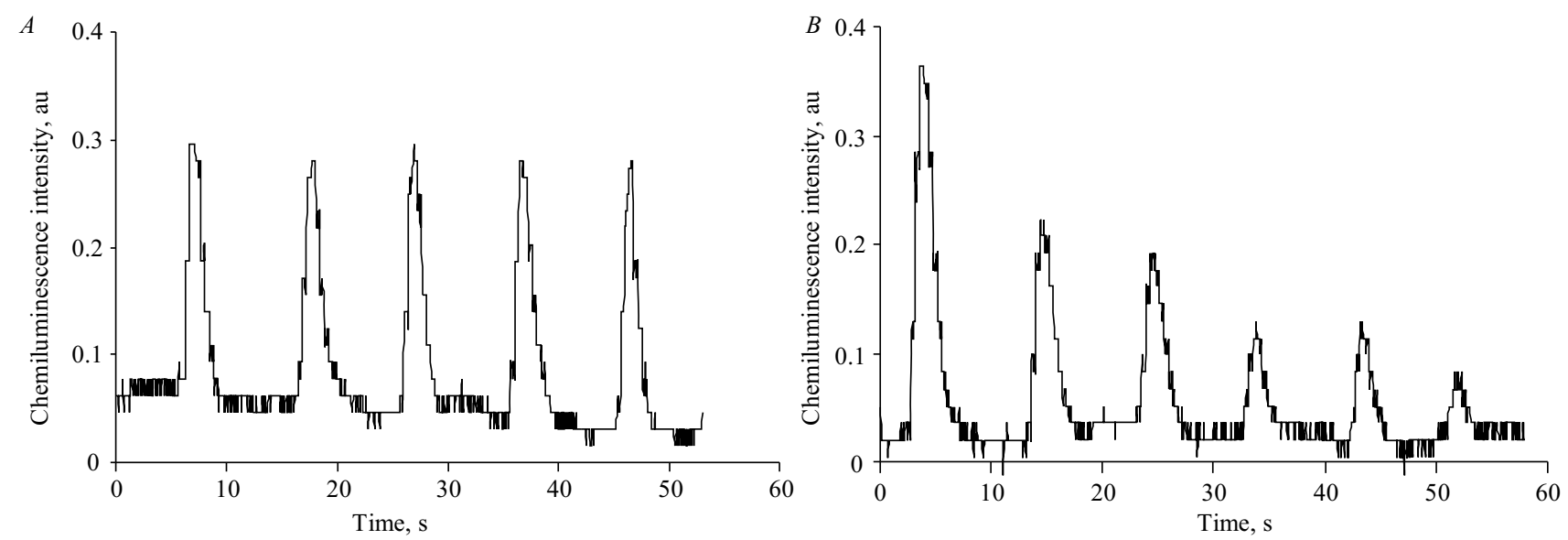

Fig. 4. The series of the chemiluminescence bursts at the consecutive introduction of the portions of the ozonous physiological saline solution into the suspension of $S$. cerevisiae cells. The ozone dose at the introduction of each OPSS portion was $30 \mathrm{pmol} / 10^{6}$ cells $(A)$ and $240 \mathrm{pmol} / 10^{6}$ cells $(B)$

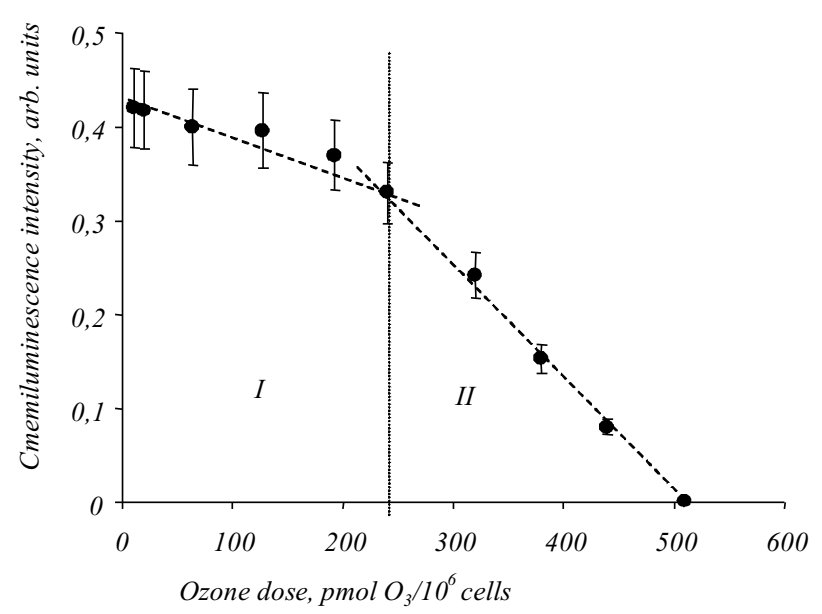

Fig. 5. The dependence of the intensity of the chemiluminescence response of $S$. cerevisiae cells on the ozone dose at the consecutive introduction of the portions of the ozonous physiological saline solution into the suspension of cells

sence with the introduction of each subsequent portion of ozone (Fig. 4, $B$ ).

Fig. 5 presents the dependence of the intensity of the CL burst (area under the burst peak) on the total dose of the introduced ozone at the consecutive introduction of the portions of the ozonous physiological saline solution into the suspension of $S$. cerevisiae cells.

In the range of low ozone doses $I$ the amplitude of the burst is less dependent on the dose compared to the range of higher doses $I I$. The salient point is used to find the value of the maximal dose, when the amplitude of the chemiluminescence burst starts decreasing rapidly with the increase of the introduced ozone dose. In this work the value of the maximal dose of ozone, found therefrom, is accepted as TAOC.

For the $S$. cerevisiae cells this value was $240 \pm 20$ $\mathrm{pmol} / 10^{6}$ cells. It corresponds to some threshold in the dose of exogenous ROS, the excess of which changes the character of the response of $S$. cerevisiae cells to the oxidative stress. In the range of doses under $240 \mathrm{pmol} /$ $10^{6}$ cells, the $S$. cerevisiae cells demonstrate their resistance to the impact of ozone. In this dose range the compensatory biological process, launched in response to the short-term impairment of homeostasis, is revealed in the form of positive impact on the cells division and growth - the hormesis [7]. It allows the assumption that at such doses of ozone the reserves of the antioxidant protection of cells are sufficient for the disposal of the introduced ozone. At the ozone doses over 240 $\mathrm{pmol} / 10^{6}$ cells the cells damage is observed. The excessive ozone is not disposed completely, there is an oxidative stress, which has the potential to cause the damage of the biologically significant molecules (nucleic acids and proteins), as well as lipids [15]. Moreover, the ROI accumulation plays an important role as a link of the programmed cell death - apoptosis, and at the high level of ROS - necrosis, which is observed in the cells of different types [16].

Conclusions. TAOC of S. cerevisiae cells was estimated as the dose of ozone, which can be neutralized by the systems of their antioxidant protection $-240 \pm 20$ pmol $/ 10^{6}$ cells. It was demonstrated that $S$. cerevisiae cells are resistant to the impact of excessive ozone at the doses, not exceeding the value of TAOC of these cells. 
Антиоксидантна ємність і стійкість до дії озону клітин Saccharomyces cerevisiae

І. П. Горяча, В. Д. Зінченко, Т. С. Дюбко, Е. О. Ромоданова, А. Л. Татарець

\section{Резюме}

Mета. Дослідження реакиії клітин S. сегеvisiae на дію озону в різних дозах і визначення загальної антиоксидантної ємності (ЗАОС) даних клітин. Методи. ЗАОС визначали хемілюмінесиентним методом за введення озону в клітини S. cеrevisiae. Пошкодження клітин виявляли методами флуоресцентної мікроскопії та проточної ичитофлуориметрії із застосуванням флуоресцентного барвника Square-460. Результати. Показано, що за дозованого введення озону у суспензію клітин $S$. сегеvisiae виникає спалах хемілюмінесиениії у відповідь на кожну нову дозу озону. Амплітуда спалаху мало змінюється за низьких доз і знижується після досягнення деякої характерної для даних клітин сумарної дози озону. При цуьому з'являються пошкоджені клітини, кількість яких збільшується з ростом дози введеного озону. Висновки. Оиінено ЗАОЄ клітин $S$. сегеvisiae як дозу озону, яку здатні нейтралізувати системи їхнього антиоксидантго захисту, ияо становить $240 \pm 20$ пмоль $/ 10^{6}$ кл. Клітини S. сегеvisiae є стійкими до дї̈надлишкового озону за його доз, які не перевищують величину ЗАОЕ даних клітин.

Ключові слова: оксидативий стрес, активні форми кисню, озон, S. сегеvisiae, хемілюмінесиенція.

Антиоксидантная емкость и устойчивость к действию озона клеток Saccharomyces cerevisiae

И. П. Горячая, В. Д. Зинченко, Т. С. Дюбко, Э. А. Ромоданова, А. Л. Татарец

Резюме

Цель. Исследование реакичи клеток S. сегеvisiae на действие озона в различных дозах и определение общей антиоксидантной емкости (ОАОЕ) данных клеток. Методы. ОАОЕ определяли хемилюминесцентным методом при введении озона в клетки S. сегеvisiae. Повреждение клеток озоном выявляли методами флуоресиентной микроскопии и проточной циттофлуориметрии с использованием флуоресиентного красителя Square-460. Результаты. Показано, что при дозированном введении озона в суспензию клеток $S$. сегеvisiae возникают вспьшки хемилюминесиенции в ответ на каждую новую дозу озона. Амплитуда вспьшки мало изменяется при низких дозах и снижается после достижения некоторой характерной для данных клеток суммарной дозы озона. При этом появляются поврежденные клетки, количество которых увеличивается с ростом дозы введенного озона. Выводы. Оиенена ОАОЕ клеток S. сегеvisiae как доза озона, которую способны нейтрализовать системы их антиоксидантной защитыь, она составляет $240 \pm 20$ пмоль $/ 10^{6}$ кл. Клетки S. сегеvisiae yстойчивы к действию избыточного озона при его дозах, не превымающих величину ОАОЕ данных клеток.

Ключевые слова: оксидативный стресс, активные формы кислорода, озон, S. сегеvisiae, хемилюминесиенция.

\section{REFERENCES}

1. Belykh IA, Zinchenko VD, Vysekantsev IP. Stimulating effect of ozone low doses on microorganisms growth. Problems of Cryobiology (Problemy Kriobiologii). 2004; (4):41-6.

2. Talbot P, Martinelli L, Talvy S, Chauveheid E, Haut B. Ozone inactivation of resistant microorganisms: Laboratory analysis and evaluation of the efficiency of plants. Water Res. 2012;46(18): 5893-903.

3. Hormesis: A Revolution in biology, toxicology and medicine. Eds MP Mattson, EJ Calabrese. New York, Humana Press Inc., 2010; 213 p.

4. Pryor WA, Houk KN, Foote CS, Fukuto JM, Ignarro LJ, Squadrito $G L$, Davies $K J$. Free radical biology and medicine: it's a gas, man! Am J Physiol Regul Integr Comp Physiol. 2006;291(3): R491-511.

5. Bocci $V$. Ozone as Janus: this controversial gas can be either toxic or medically useful. Mediators Inflamm. 2004;13(1):3-11.

6. Davies JM, Lowry CV, Davies KJ. Transient adaptation to oxidative stress in yeast. Arch Biochem Biophys. 1995;317(1):1-6.

7. Zinchenko VD, Belykh IA, Buryak IA, Goriacha IP, Govor IV. Induction of the effects of crossed adaptation using oxidative stress to increase the efficiency of cryopreservation of biological objects. Actual problems of cryobiology and cryomedicine. Ed. AN Goltsev. Kharkiv, 2012; 271-94.

8. Karadag A, Ozcelik B, Saner $S$. Review of methods to determine antioxidant capacities. Food Anal Methods. 2009;2(1):41-60.

9. Tirzitis $G$, Bartosz $G$. Determination of antiradical and antioxidant activity: basic principles and new insights. Acta Biochim Pol. 2010;57(2):139-42.

10. Gerardi G, Usberti M, Martini G, Albertini A, Sugherini L, Pompella $A$, Di LD. Plasma total antioxidant capacity in hemodialyzed patients and its relationships to other biomarkers of oxidative stress and lipid peroxidation. Clin Chem Lab Med. 2002;40 (2):104-10.

11. Ramanathan B, Jan KY, Chen CH, Hour TC, Yu HJ, Pu YS. Resistance to paclitaxel is proportional to cellular total antioxidant capacity. Cancer Res. 2005;65(18):8455-60.

12. Filippov JV, Voblikova VA, Panteleev VI. Electrosynthesis of ozone. M.: Moscow University Publishing House. 2008; 237 p.

13. Lunin VV, Popovich MP, Tkachenko SN. Physical chemistry of ozone. Moscow: University Publ., 1998; 480 p.

14. Pat. N 72111. Ukraine G01N 21. 76 (2006.01). Bioluminometer. VD Zinchenko, IP Goriacha, IV Govor. An. 05.01.2012. Publ. 15.08.2012. Bul. N 15.

15. Kohen R, Nyska A. Oxidation of biological systems: oxidative stress phenomena, antioxidants, redox reactions, and methods for their quantification. Toxicol Pathol. 2002;30(6):620-50.

16. Fulda $S$, Gorman AM, Hori $O$, Samali A. Cellular stress responses: cell survival and cell death. Int J Cell Biol. 2010;2010:214074.

Received 03.09.13 